\title{
Myelin Oligodendrocyte Gene Polymorphisms and Childhood Multiple Sclerosis
}

\author{
ANDREAS OHLENBUSCH, DANIELA POHL, AND FOLKER HANEFELD \\ Abteilung Pädiatrie, Schwerpunkt Neuropädiatrie, Georg-August-Universität, 37075 Göttingen, Germany
}

\begin{abstract}
ABS
Myelin oligodendrocyte glycoprotein (MOG) is a quantita-
tively minor glycoprotein of the CNS localized preferentially on
the outermost myelin lamellae and the oligodendrocyte plasma
membrane. In several animal models, MOG displays highly
immunogenic properties by inducing a severe multiple sclerosis-
like disease, characterized by inflammatory demyelinating le-
sions. Immunologic findings implicate MOG as a target autoan-
tigen in multiple sclerosis. We have performed a molecular study
on the MOG gene by sequencing the promotor and the entire
coding region, as well as the exon-intron boundaries, in 75
children with multiple sclerosis. A total of five unknown poly-
morphic sites in the promotor region not affecting any of the
putative cis-acting transcriptional regulation motifs as well as
nine additional base changes in four different exons each with
\end{abstract}
similar distribution in patients and controls $(n=100)$ were detected. Exon 2 coding for the Ig-like domain revealed two rare heterozygous missense mutations, possibly altering favorable conformational epitopes ( $\mathrm{P} 43 \mathrm{H}$; R66P). P43 is part of the encephalitogenic epitope $\mathrm{MOG}_{35-55}$. A putative $\mathrm{C} 1 \mathrm{q}$ binding site in the $C^{\prime \prime}-\mathrm{D}$ loop of the Ig superfamily motif encompasses R66. In conclusion, the polymorphisms observed do not provide evidence to support a significant role for MOG in multiple sclerosis susceptibility. (Pediatr Res 52: 175-179, 2002)

\section{Abbreviations}

EAE, experimental autoimmune encephalomyelitis

MOG, myelin oligodendrocyte protein

MS, multiple sclerosis
MOG is a CNS-specific integral membrane protein of 26-28 $\mathrm{kD}$, preferentially expressed on the outermost lamellae of myelin and on the surface of oligodendrocytes (1). It is a minor component of myelin, constituting $0.01-0.05 \%$ of total myelin proteins $(2,3)$. The sequences of MOG cDNA from rat, mouse, bovine, and human show that the mature MOG protein is a 218-amino acid member of the Ig superfamily (4-7), with its single glycosylated Ig-like domain located to the extracellular surface of the plasma membrane and thus directly accessible to a humoral immune response (8).

The expression of MOG is late in oligodendrocyte differentiation and shows a caudal-rostral gradient throughout development $(5,9,10)$. However, its biologic function remains unknown. Given its biochemical properties, MOG might be actively involved in the completion of the myelinating process or might be part of the network to maintain the compaction of myelin by modulating the dynamics of microtubule stabilization in oligodendrocytes [reviewed in Johns and Bernard (11)].

A predominant T-cell response to MOG and the presence of anti-MOG antibodies in patients with MS implicate MOG as an

Received December 19, 2001; accepted March 11, 2002.

Correspondence and reprint requests: Prof. Dr. F. Hanefeld, Schwerpunkt Neuropädiatrie, Georg-August-Universität, Robert-Koch-Str. 40, 37075 Göttingen, Germany; e-mail: hanefeld@med.uni-goettingen.de

Supported by grants from the Gemeinnützige Hertie Stiftung (Project GHS2/342/95).

DOI: 10.1023/01.PDR.0000019496.45732.3A attractive target autoantigen in MS (12-17). EAE, the most widely used animal model of MS, is a $\mathrm{CD} 4^{+} \mathrm{T}$ cell-mediated disease. Depending on the species, EAE can be induced either actively with purified or recombinant MOG or MOG-derived peptides or transferred by $\mathrm{T}$ cells and antibodies reactive against MOG [(18-22), reviewed in 't Hart et al. (23)]. Furthermore, comparative observations of acute lesions in MS patients and in the nonhuman primate models of EAE underscore the potential role of anti-MOG autoantibodies in the destruction of myelin in both MS plaques and EAE lesions (24, 25).

MS is presumed to be a multifactorial autoimmune disease. However, despite extensive efforts to identify a single locus determining susceptibility to MS, a consistent albeit weak association or linkage has been reported only for the HLA region on 6p21 (26-29). Reports demonstrating positive results for other candidate genes have been difficult to replicate beyond the population studied and provided contradictory results.

The human MOG locus has been mapped to the HLA region on chromosome 6p21 and has been shown to be less than 100 $\mathrm{kb}$ telomeric to HLA-F in the class $1 \mathrm{~b}$ region in a head-to-head orientation (30). In line with other myelin genes (31), the $M O G$ gene is composed of 11 exons demonstrating a complex array of alternatively spliced isoforms $(32,33)$. However, apart from the original MOG transcript, none of the 12 splice variants 
known at the mRNA level have been detected at the protein level. Inclusion of exon 3 encoding a short hydrophilic domain would result in a truncated form of MOG (33).

Considering the immunologic and genetic implications, we have performed a comprehensive molecular analysis on the $M O G$ gene in childhood MS. In the present report, we describe an efficient long-range PCR method for amplifying the entire $M O G$ gene as two single amplicons for mutational analysis. Sequencing was performed for the entire coding region and the exon-intron splice junctions, as well as for parts of the intervening intronic sequences. The analysis included also $1200 \mathrm{bp}$ of the 5'-flanking region sufficient for high level activity in the mouse model of promotor efficiency (34).

\section{METHODS}

Patients and control subjects. A total of 75 unrelated children of German origin ( 46 girls aged 8 to $19 \mathrm{y}$ with a median of $13 \mathrm{y}$ and 29 boys aged 7 to $18 \mathrm{y}$ with a median of $14 \mathrm{y}$ ) were selected from a study on inflammatory demyelination $(35,36)$. All patients fulfilled the established criteria for clinically defined and laboratory supported MS (37). It was established during these studies that MS in adults and childhood is basically the same disease. The control group $(n=100)$ matched with the MS patients for ethnic origin, age, and sex to reduce the risk of introducing population stratification artifacts. The study was approved by the local ethics committee, and informed consent by the parents was obtained for each patient.

DNA isolation and long-range PCR. Total genomic DNA was extracted from peripheral blood by standard techniques. With the exception of the 3'-untranslated region, the entire MOG gene was amplified by two overlapping PCR fragments with the Expand Long Template PCR System (Roche Molecular Products, Mannheim, Germany) according to the manufacturer's recommendations with some modifications. Primers were designed according to the published human genomic DNA sequence (38). For fragment A (MOGA, Table 1) samples were initially denatured at $94^{\circ} \mathrm{C}$ for $2 \mathrm{~min}$, before undergoing 10 cycles of $94^{\circ} \mathrm{C}$ for $10 \mathrm{~s}, 66^{\circ} \mathrm{C}$ for $30 \mathrm{~s}$, and $68^{\circ} \mathrm{C}$ for $9.5 \mathrm{~min}$. For the subsequent 19 cycles, elongation increased
$20 \mathrm{~s}$ each cycle, with a final extension of $7 \mathrm{~min}$ at $68^{\circ} \mathrm{C}$. For fragment $\mathrm{B}$ (MOGB) thermocycler conditions (Personal $\mathrm{Cy}-$ cler, Biometra, Göttingen, Germany) were $94^{\circ} \mathrm{C}$ for 2 min, followed by 10 cycles at $94^{\circ} \mathrm{C}$ for $10 \mathrm{~s}, 65^{\circ} \mathrm{C}$ for $30 \mathrm{~s}$, and $68^{\circ} \mathrm{C}$ for $3.75 \mathrm{~min}$. For the subsequent 17 cycles annealing and extension were at $68^{\circ} \mathrm{C}$ for $4.25 \mathrm{~min}$ with a cycle elongation of $20 \mathrm{~s}$ for each cycle. A final prolonged extension step was performed for $7 \mathrm{~min}$ at $68^{\circ} \mathrm{C}$. Reactions contained $50 \mathrm{mM}$ Tris- $\mathrm{HCl}$ ( $\mathrm{pH}$ 9.2), $16 \mathrm{mM}\left(\mathrm{NH}_{4}\right) \mathrm{SO}_{2}, 32.5 \mathrm{mM}$ (for MOGA), and $27.5 \mathrm{mM}$ (for MOGB) $\mathrm{MgCl}_{2}, 500 \mu \mathrm{M}$ each dNTP, 0.4 $\mu \mathrm{M}$ (for MOGA) and $0.3 \mu \mathrm{M}$ (for MOGB) each primer, and 500 ng of template DNA. PCR products were subsequently purified by Ultrafree-MC 30,000 NMWL Filter Units (Millipore Corporation, Bedford, MA, U.S.A.). The strategy to minimize errors caused by PCR reactions involved the pooling of three independent PCR reactions for each fragment to be sequenced.

DNA sequencing. For direct sequencing each region of interest was PCR-cycled with the indicated primers (Table 1). The BigDye terminator cycle sequencing program consisted of 25 cycles of $94^{\circ} \mathrm{C}$ for $10 \mathrm{~s}$ and $60^{\circ} \mathrm{C}$ for $4 \mathrm{~min}$. Data were selected using a model 377 sequencer (Applied Biosystems, Foster City, CA, U.S.A.) with model 48E-1200. Automated sequence comparison for mutation detection was performed with the Sequence Navigator Software (Applied Biosystems). In cases of ambiguities, a second independent PCR approach on the genomic DNA level or antisense sequencing was applied to confirm the observed mutation.

Statistical analysis. Allelic distributions for MOG were compared between normal and MS individuals by applying the $\chi^{2}$ or Fisher's exact test. Bonferroni correction for multiple testing was done when necessary. Five percent was chosen as the level of significance $(p<0.05)$.

\section{RESULTS}

The $M O G$ gene was amplified to facilitate mutational analysis by direct automated fluorescent DNA sequencing of all 11 exons and the exon-intron junctions, as well as of $1200 \mathrm{bp}$ of the promotor region, from 75 unrelated children with MS and

Table 1. PCR primers for long-range amplification and sequencing reactions

\begin{tabular}{|c|c|c|}
\hline Primer Type & & Product Size \\
\hline \multicolumn{3}{|l|}{ Long-range PCR } \\
\hline Fragment & 5'-GTCTGATGAGATAACCACTAACTTGAGTGC-3' & $11.8 \mathrm{~kb}$ \\
\hline MOG-A & 5'-GGAACTTACCAAAAGTCCGGTGGAG-3' & \\
\hline MOG-B & 5'-TGTCCTTAGCCAGAGAGGGCTTCCAGG-3' & \\
\hline Sequencing & & Expected Read Length Ranges \\
\hline Promotor, Exon 1 & 5'-ACAGGGCAGAGTTTGGATTCGCGGTAG-3' & 750 \\
\hline Exon 2 & 5'-GGCGACAGAGAGTAAGACTGTCTC-3' & 820 \\
\hline Exon 3 & 5'-TTCACGTCACATTAGAAAAGTCACAG-3' & 420 \\
\hline Exon 4 & 5'-GGCTGACCCAATACACAATCTTGAC-3' & 820 \\
\hline \multicolumn{3}{|l|}{ MOGB } \\
\hline Exons 5,6 & 5'-GAGAAAGAGCCGCAACCATTGGC-3' & 750 \\
\hline
\end{tabular}


100 healthy control subjects. We used the long expand technique to generate two overlapping PCR fragments covering $15.3 \mathrm{~kb}$ of the $M O G$ gene. Screening for sequence variants did not reveal any base changes within the consensus sequences of the exon-intron junctions or in exons 3 (soluble MOG), 5, 6, 7, 9, 10A, and 10B (cytoplasmic regions). Larger rearrangements caused by deletions or insertions were not detected.

Variability of the human MOG gene. We identified a total of 16 intronic polymorphisms each with similar allele frequencies in patients and controls and with a range varying between $0.9 \%$ and $16.6 \%$ (data not shown). Base changes within the promotor region and in expressed sequences are summarized in Table 2. Of a total of 75 patients examined, five base substitutions were found in the 5'-flanking region of the $M O G$ gene. The sequence coding for the signal peptide (exon 1) revealed a $\mathrm{G}$ to $\mathrm{A}$ transition at nucleotide position 15 , which is predicted to cause a silent mutation and has also been found by reverse transcription-PCR analysis of normal human CNS RNA samples (33). The heterozygous deletion of codon 22 within the signal peptide $(\triangle \mathrm{CTC})$ was always accompanied by polymorphisms within the 5 '-flanking region at $\mathrm{nt}(-910), \operatorname{nt}(-875)$, and $\mathrm{nt}(-93)$ both in MS patients and in controls. The haplotype $[-910 \mathrm{~T} / \mathrm{C},-875 \mathrm{~A} / \mathrm{C},-93 \mathrm{~T} / \mathrm{C}, 64-66 \mathrm{CTC} / \Delta \mathrm{CTC}]$ was under-represented in the MS population, but this difference was not significant. Three distinct silent transitions were identified in exons 2 and 8 (A306G, C336T, and G672A). Two heterozygous missense mutations were detected in exon 2 coding for the Ig-like domain of the protein. The Pro to His exchange at amino acid position 43 was found both in MS patients and in one control subject's chromosome. The heterozygous $\mathrm{G}$ to $\mathrm{C}$ transversion at nucleotide 284 resulting in Arg to Pro at residue 66 was found in a 16-year-old patient with no positive family history of MS. This mutation was inherited through her unaffected mother as revealed by genomic DNA analysis and was subsequently not found in her 14-year-old healthy sister. In addition to these rare substitutions, two missense mutations within exon 4 were found to be particularly common (Val142Leu, Val145Ile).
In summary, the distribution of alleles was similar in patients and in control subjects for all substitutions identified ( $p$ $>0.05)$. No statistically significant association or haplotype with predisposition for MS was observed, even after stratification of data for HLA status as well as of patients for severity or temporal course of disease and combinations thereof.

\section{DISCUSSION}

The substantial genetic component in the etiology of MS has been established by studies in twins, adoptees, and half siblings and by the occurrence of familial clusterings of MS cases (3941). With the exception of the MHC region, the lack of a major MS gene is highlighted by independent systematic genome-wide searches for linkage in multiplex families (27-29, 42-46).

We have performed a detailed mutational analysis of the $M O G$ gene within a patient group of moderate size $(n=75)$. We found a total of nine polymorphisms in four different exons (Table 2), each with similar frequencies in patients and control subjects. None of the substitutions observed confer obviously major deleterious effects on the function of the protein. A trend exists toward the clustering of base substitutions as four of them occurred within exon 2 coding for the Ig-like domain of the protein.

MOG is the focus of both a $\mathrm{T}$ cell- and an antibodymediated immune attack in MS (14-17). Polymorphisms (such as $\mathrm{P} 43 \mathrm{H}$ or R66P; Table 2) may influence the state of tolerance or may modulate the generation of anti-MOG antibody responses in a subset of patients with the appropriate genetic (MHC) background or may even be involved in determinant spreading as a result of ongoing demyelination. By considering the disease heterogeneity (47), anti-MOG antibodies have been described in lesions of acute MS and the marmoset model of EAE (25). T-cell autoreactivity to MOG in rhesus monkeys immunologically closely related to humans was directed against $\mathrm{MOG}_{35-50}$, which was also an immunodominant epitope for the T-cell response to MOG in patients with MS (48). Furthermore, recent studies suggest that the immunodominant demyelinating autoantibody response to MOG is confor-

Table 2. MOG-specific polymorphisms in MS $(n=75)$ and control subjects $(n=100)$

\begin{tabular}{|c|c|c|c|c|c|c|c|c|c|c|c|c|c|c|}
\hline \multirow[b]{3}{*}{ Nucleotide* } & \multirow[b]{3}{*}{ Location } & \multirow[b]{3}{*}{ Aa Variant } & \multirow{2}{*}{\multicolumn{2}{|c|}{ Allele }} & \multicolumn{3}{|c|}{ MS } & \multicolumn{3}{|c|}{ Controls } & \multicolumn{2}{|c|}{ MS } & \multicolumn{2}{|c|}{ Controls } \\
\hline & & & & & \multicolumn{3}{|c|}{ Genotypes (\%) } & \multicolumn{3}{|c|}{ Genotypes (\%) } & \multicolumn{2}{|c|}{ Frequencies $(\%)$} & \multicolumn{2}{|c|}{ Frequencies $(\%)$} \\
\hline & & & 1 & 2 & $1 / 1$ & $1 / 2$ & $2 / 2$ & $1 / 1$ & $1 / 2$ & $2 / 2$ & 1 & 2 & 1 & 2 \\
\hline-1077 & 5'-flanking & - & $\mathrm{T}$ & $\mathrm{C}$ & 96.0 & 4.0 & 0 & 97.0 & 3.0 & 0 & 98.0 & 2.0 & 98.5 & 1.5 \\
\hline-918 & $5^{\prime}$-flanking & - & G & A & 96.0 & 4.0 & 0 & 98.0 & 2.0 & 0 & 98.0 & 2.0 & 99.0 & 1.0 \\
\hline-910 & 5'-flanking & - & $\mathrm{T}$ & $\mathrm{C}$ & 90.7 & 9.3 & 0 & 88.0 & 12.0 & 0 & 95.3 & 4.7 & 94.0 & 6.0 \\
\hline-875 & $5^{\prime}$-flanking & - & A & $\mathrm{C}$ & 90.7 & 9.3 & 0 & 88.0 & 12.0 & 0 & 95.3 & 4.7 & 94.0 & 6.0 \\
\hline-93 & $5^{\prime}$-flanking & - & $\mathrm{T}$ & $\mathrm{C}$ & 90.7 & 9.3 & 0 & 88.0 & 12.0 & 0 & 95.3 & 4.7 & 94.0 & 6.0 \\
\hline 15 & Exon 1 & $\mathrm{~S} 5 \mathrm{~S} \uparrow$ & G & A & 78.7 & 17.3 & 4.0 & 76.0 & 19.0 & 5.0 & 87.4 & 12.6 & 85.5 & 14.5 \\
\hline $64-66$ & Exon 1 & $\operatorname{del} 22 \mathrm{~L} \dagger$ & CTC & $\Delta \mathrm{CTC}$ & 90.7 & 9.3 & 0 & 88.0 & 12.0 & 0 & 95.3 & 4.7 & 94.0 & 6.0 \\
\hline 215 & Exon 2 & $\mathrm{P} 43 \mathrm{H}$ & $\mathrm{C}$ & A & 97.3 & 2.7 & 0 & 99.0 & 1.0 & 0 & 98.7 & 1.3 & 99.5 & 0.5 \\
\hline 284 & Exon 2 & $\mathrm{R} 66 \mathrm{P}$ & G & $\mathrm{C}$ & 98.7 & 1.3 & 0 & 100 & 0 & 0 & 99.3 & 0.7 & 100 & 0 \\
\hline 306 & Exon 2 & $\mathrm{~K} 73 \mathrm{~K}$ & A & G & 94.7 & 5.3 & 0 & 98.0 & 2.0 & 0 & 97.3 & 2.7 & 99.0 & 1.0 \\
\hline 336 & Exon 2 & L83L & $\mathrm{C}$ & $\mathrm{T}$ & 98.7 & 1.3 & 0 & 99.0 & 1.0 & 0 & 99.3 & 0.7 & 99.5 & 0.5 \\
\hline 511 & Exon 4 & V142L & G & $\mathrm{C}$ & 54.7 & 41.3 & 4.0 & 57.0 & 36.0 & 7.0 & 75.3 & 24.7 & 75.0 & 25.0 \\
\hline 520 & Exon 4 & V145I & G & A & 82.7 & 17.3 & 0 & 88.0 & 9.0 & 3.0 & 91.3 & 8.7 & 92.5 & 7.5 \\
\hline 672 & Exon 8 & L195L & G & A & 98.7 & 1.3 & 0 & 98.0 & 2.0 & 0 & 99.3 & 0.7 & 99.0 & 1.0 \\
\hline
\end{tabular}

* Nucleotide positions $(7,32,38)$.

$\dagger$ Numbering of the signal peptide. 
mation dependent [reviewed in Stefferl et al. (49) and Iglesias et al. (50)] and may mediate demyelination only in a small subset of MS cases (16).

In addition, $\mathrm{Arg}^{66}$ is part of the complement-binding motif $\mathrm{Glu}^{64}-\mathrm{X}-\mathrm{Arg}^{66}-\mathrm{X}-\mathrm{Arg}^{68}$ similar to the $\mathrm{Clq}$ binding site $\mathrm{Glu}^{318}$ $\mathrm{X}-\mathrm{Lys}^{320}-\mathrm{X}-\mathrm{Lys}^{322}$ within the $\mathrm{CH} 2$ domain on IgG molecules (51) and might directly activate the classic complement pathway. It has been shown that purified native MOG and the recombinant extracellular Ig-like domain of MOG both bind $\mathrm{C} 1 \mathrm{q}$ in a dose-dependent manner (52).

The encephalitogenicity as well as the T- and B-cell responses to MOG peptides harboring the identified mutations might be assessed in the EAE model of MS. In addition, synthetic peptides overlapping amino acid positions 43 and 66 might be constructed to identify the effects for the autoimmune T-cell response in MS patients by establishing a PBL proliferation assay.

The concept of molecular mimicry is still an attractive but unresolved issue in MS to explain immune-mediated injury to normal tissue. The possibility of stimulating MBP-specific T-cell clones established from MS patients by structurally related viral and bacterial peptides (not necessarily the sequence) has been demonstrated (53). The possible involvement of environmental pathogens in the induction of MS has been shown by molecular mimicry between Semliki Forest Virus (SFV) peptide E2 ${ }_{115-129}$ and $\mathrm{MOG}_{18-32}$. Both of them were capable of inducing a later-onset chronic EAE-like disease in C57B16/J mice that correlated with histopathologic signs of vacuolation in the CNS white matter (54). Amino acid substitutions (Table 2) may have an influence on cross-reactivity if the appropriate immunologic background is available. Further studies should provide more information about the spectrum of epitopes from self- and pathogen-derived antigens.

There has been no functional analysis of the human MOG promotor up to now. A comparable study of the mouse MOG 5 '-flanking region suggests that potential regulatory elements in the proximal -657 region were sufficient for high-level activity (34). We have identified five previously unknown base substitutions within the 5'-flanking region (Table 2), which are not part of the suggested protein-DNA interfaces (38). Given that three purine-rich cis-regulatory motifs, which are thought to be important for the expression of other myelin genes, including MBP, PLP, 2',3'-cyclic nucleotide 3'-phosphodiesterase, MAG, and $\mathrm{P}_{0}$ [reviewed in Hudson et al. (55)], were not included in the -657-bp region, novel and as yet uncharacterized positive regulatory motifs may account for the maximal expression in the mouse model of the MOG promotor efficiency (34).

The substitution of isoleucine for valine at amino acid position 145 (exon 4) has also been used for a case-control association study from France (56). In line with our results (Table 2), this variant is not associated with an increased MS susceptibility. Conflicting results have been obtained by analyzing microsatellite markers. MOGc (38), located within the $M O G$ gene, revealed significant differences in allele frequencies between white MS patients and control subjects (57). These findings could in part be explained assuming the disease-associated, extended HLA haplotype and the apparent linkage disequilibrium in this region. However, one of the observed allelic associations was independent of the DRB1*1501 effect. No significantly different MOG haplo- types were detected in an association study from France using three microsatellites-MOGc and two located upstream of the MOG transcription start site $(58,59)$. Linkage analysis to four markers performed in multiplex MS families revealed a potential role of MOG (60).

Assessing association with the case-control method can be prone to biases owing to population stratification, admixture artifacts, or limited statistical power $(61,62)$. The genetic dissection of MS also is hampered by several basic unsolved problems, e.g. incomplete penetrance, locus heterogeneity, or polygenic inheritance. The importance of ethnic and clinically homogeneous and comparable study groups was illustrated by analyzing an $M O G$ gene restriction fragment length polymorphism, revealing inconsistent results $(7,63)$.

In conclusion, the variations in the coding sequences and the upstream region of the $M O G$ gene do not play a significant role in the pathology of MS and probably of EAE as well. Evidence for an association with a certain MOG haplotype was not provided after data stratification for severity or temporal course of disease or for the HLA status and combinations thereof ( $p>$ $0.05)$. However, to verify the significance of variations, a comprehensive analysis of a larger group of patients with MS is necessary to create HLA/MOG haplotypes, which may correlate with B- and T-cell responses to MOG. Further investigations may also provide insight into the $3^{\prime}$ untranslated region of the $M O G$ gene, which was not included in this study.

Acknowledgment. The authors thank E. Krämer for excellent technical assistance.

\section{REFERENCES}

1. Brunner C, Lassmann H, Waehneldt TV, Matthieu JM, Linington C 1889 Differential ultrastructural localization of myelin basic protein, myelin/oligodendroglial glycoprotein, and 2',3'-cyclic nucleotide 3'-phosphodiesterase in the CNS of adult rats. J Neurochem 52:296-304

2. Amiguet P, Gardinier MV, Zanetta JP, Matthieu JM 1992 Purification and partial structural and functional characterization of mouse myelin/oligodendrocyte glycoprotein. J Neurochem 58:1676-1682

3. Abo S, Bernard CCA, Webb M, Johns TG, Alafaci A, Ward LD, Simpson RJ, Kerlero de Rosbo N 1993 Preparation of highly purified human myelin oligodendrocyte glycoprotein in quantities sufficient for encephalitogenicity and immunogenicity studies. Biochem Mol Biol Int 30:945-958

4. Gardinier MV, Amiguet P, Linington C, Matthieu JM 1992 Myelin/oligodendrocyte glycoprotein is a unique member of the immunoglobulin superfamily. J Neurosci Res 33:177-187

5. Pham-Dinh D, Mattei MG, Nussbaum JL, Roussel G, Pontarotti P, Roeckel N, Mather IH, Artz K, Fisher Lindhal K, Dautigny A 1993 Myelin/oligodendrocyte glycoprotein is a member of a subset of the immunoglobulin superfamily encoded within the major histocompatibility complex. Proc Natl Acad Sci USA 90:7990-7994

6. Pham-Dinh D, Allinquant B, Ruberg M, Della Gaspera B, Nussbaum JL, Dautigny A 1994 Characterization and expression of the cDNA coding for the human myelin/ oligodendrocyte glycoprotein. J Neurochem 63:2353-2356

7. Hilton AA, Slavin AJ, Hilton DJ, Bernard CCA 1995 Characterization of cDNA and genomic clones encoding human myelin oligodendrocyte glycoprotein. J Neuroimmunol 65:309-318

8. Kroepfl JF, Viise LR, Charron AJ, Linington C, Gardinier MV 1996 Investigation of myelin/oligodendrocyte glycoprotein membrane topology. J Neurochem 67:2219-2222

9. Solly SK, Thomas JL, Monge M, Demerens C, Lubetzki C, Gardinier MV, Matthieu JM, Zalc B 1996 Myelin/oligodendrocyte glycoprotein (MOG) expression is associated with myelin deposition. Glia 18:39-48

10. Slavin AJ, Johns TG, Orian JM, Bernard CC 1997 Regulation of myelin oligodendrocyte glycoprotein in different species throughout development. Dev Neurosci 19:69-78

11. Johns TG, Bernard CCA 1999 The structure and function of myelin oligodendrocyte glycoprotein. J Neurochem 72:1-9

12. Sun J, Link H, Olsson T, Xiao BG, Andersson G, Ekre HP, Linington C, Diener P $1991 \mathrm{~T}$ and B cell responses to myelin-oligodendrocyte glycoprotein in multiple sclerosis. J Immunol 146:1490-1495

13. Kerlero de Rosbo N, Milo R, Lees MB, Burger D, Bernard CCA, Ben-Nun A 1993 Reactivity to myelin antigens in multiple sclerosis. J Clin Invest 92:2602-2608 
14. Kerlero de Rosbo N, Hoffmann M, Mendel I, Yust I, Kaye J, Bakimer R, Flechter S, Abramsky O, Milo R, Karni A, Ben-Nun A 1997 Predominance of the autoimmune response to myelin oligodendrocyte glycoprotein (MOG) in multiple sclerosis: reactivity to the extracellular domain of MOG is directed against three main regions. Eur J Immunol 27:3059-3069

15. Wallström E, Kdademi M, Andersson M, Weissert R, Linington C, Olsson T 1998 Increased reactivity to myelin oligodendrocyte glycoprotein peptides and epitope mapping in HLA DR2 $(15)^{+}$multiple sclerosis. Eur J Immunol 28:3329-3335

16. Haase CG, Guggenmos J, Brehm U, Andersson M, Olsson T, Reindl M, Schneidewind JM, Zettl UK, Heidenreich F, Berger T, Wekerle H, Hohlfeld R, Linington C 2001 The fine specificity of the myelin oligodendrocyte glycoprotein autoantibody response in patients with multiple sclerosis and normal healthy controls. J Neuroimmunol 114:220-225

17. Hellings N, Baree M, Verhoeven C, D'hooghe MB, Medaer R, Bernard CC, Raus J, Stinissen P 2001 T-cell reactivity to multiple myelin antigens in multiple sclerosis patients and healthy controls J Neurosci Res 63:290-302

18. Johns TG, Kerlero de Rosbo N, Menon KK, Abo S, Gonzalesm MF, Bernard CCA 1995 Myelin oligodendrocyte glycoprotein induces a demyelinating encephalomyelitis resembling multiple sclerosis. J Immunol 154:5536-5541

19. Slavin A, Ewing C, Liu J, Ichikawa M, Slavin J, Bernard CCA 1998 Induction of a multiple sclerosis-like disease in mice with an immunodominant epitope of myelin oligodendrocyte glycoprotein. Autoimmunity 28:109-120

20. Stefferl A, Brehm U, Storch M, Lambrecht-Washington D, Bourquin C, Wonigeit K, Lassmann H, Linington C 1999 Myelin oligodendrocyte glycoprotein induces experimental autoimmune encephalomyelitis in the "resistant" brown Norway rat: disease susceptibility is determined by MHC and MHC-linked effects on the B cell response. J Immnunol 163:40-49

21. Mendel I, Gur H, Kerlero de Rosbo N, Ben-Nun A 1999 Experimental autoimmune encephalomyelitis induced in B6.C-H-2 $2^{\mathrm{bm} 12}$ mice by myelin oligodendrocyte glycoprotein: effect of MHC class II mutation on immunodominant epitope selection and fine epitope specificity of encephalitogenic T cells. J Neuroimmunol 96:9-20

22. Villoslada P, Abel K, Heald N, Goertsches R, Hauser SL, Genain CP 2001 Frequency, heterogeneity and encephalitogenicity of $\mathrm{T}$ cells specific for myelin oligodendrocyte glycoprotein in naive outbred primates Eur J Immunol 31:2942-2950

23. 't Hart BA, van Meurs M, Brok HP, Massacesi L, Bauer J, Boon L, Bontrop RE, Laman JD 2000 A new primate model for multiple sclerosis in the common marmoset. Immunol Today 21:290-297

24. Raine CS, Cannella B, Hauser SL, Genain CP 1999 Demyelination in primate autoimmune encephalomyelitis and acute multiple sclerosis lesions: a case for antigen-specific antibody mediation. Ann Neurol 46:144-160

25. Genain C, Cannella B, Hauser SL, Raine C 1999 Identification of autoantibodies associated with myelin damage in multiple sclerosis. Nat Med 5:170-175

26. Haines JL, Ter-Minassian M, Bazyk A, Gusella JF, Kim DJ, Terwedow H, PericakVance MA, Rimmler JB, Haynes CS, Roses AD, Lee A, Shaner B, Menold M, Seboun E, Fitoussi RP, Gartioux C, Reyes C, Ribierre F, Gyapay G, Weissenbach J, Hauser SL, Goodkin DE, Lincoln R, Usuku K, Oksenberg JR 1996 A complete genomic screen for multiple sclerosis underscores a role for the major histocompatibility complex. Nat Genet 13:469-471

27. Sawcer S, Jones HB, Feakes R, Gray J, Smaldon N, Chataway J, Robertson N, Clayton D, Goodfellow PN, Compston A 1996 A genome screen in multiple sclerosis reveals susceptibility loci on chromosome $6 \mathrm{p} 21$ and 17q22. Nat Genet 13:464-468

28. Kuokkanen S, Gschwend M, Rioux JD, Daly MJ, Terwilliger JD, Tienari PJ, Wikstrom J, Palo J, Stein LD, Hudson TJ, Lander ES, Peltonen L 1997 Genomewide scan of multiple sclerosis in Finnish multiplex families. Am J Hum Genet 61:1379-1387

29. Haines JL, Terwedow HA, Burgess K 1998 Linkage to the MHC to familial multiple sclerosis suggests genetic heterogeneity. Hum Mol Genet 7:1229-1234

30. Pham-Dinh D, Jones EP, Pitiot G, Della Gaspera B, Daubas P, Mallet J, Le Paslier D, Fischer Lindahl K, Dautigny A 1995 Physical mapping of the human and mouse MOG gene at the distal end of the MHC class Ib region. Immunogenetics 42:386-391

31. Stamm S, Zhang MQ, Marr TG, Helfman DM 1994 A sequence compilation and comparison of exons that are alternatively spliced in neurons. Nucleic Acids Res 22:1515-1526

32. Pham-Dinh D, Gaspera BD, Kerlero de Rosbo N, Dautigny A 1995 Structure of the human myelin/oligodendrocyte glycoprotein gene and multiple alternative spliced isoforms. Genomics 29:345-352

33. Ballenthin PA, Gardinier MV 1996 Myelin/oligodendrocyte glycoprotein is alternatively spliced in humans but not mice. J Neurosci Res 46:271-281

34. Solly SK, Daubas P, Monge M, Dautigny A, Zalc B 1997 Functional analysis of the mouse myelin/oligodendrocyte glycoprotein gene promotor in the oligodendroglial CG4 cell line. J Neurochem 68:1705-1711

35. Hanefeld F, Bauer HJ, Christen HJ, Kruse B, Bruhn H, Frahm J 1991 Multiple sclerosis in childhood: report of 15 cases. Brain Dev 13:410-416

36. Hanefeld F, Christen HJ, Kruse B, Bauer HJ 1993 Childhood and juvenile multiple sclerosis. In: Bauer HJ, Hanefeld FA (eds) Multiple sclerosis. Its impact from childhood to old age. WB Saunders, London, pp 14-52

37. Poser CM, Paty DW, Scheinberg L, McDonald WI, Davis FA, Ebers GC, Johnson KP, Sibley WA, Silberberg DH, Tourtellotte WW 1983 New diagnostic criteria for multiple sclerosis: guidelines for research protocols. Ann Neurol 13:227-231

38. Roth MP, Malfroy L, Offer C, Sevin J, Enault G, Borot N, Pontarotti P, Coppin H 1995 The human myelin oligodendrocyte glycoprotein (MOG) gene: complete nucleotide sequence and structural characterization. Genomics 28:241-250
39. Mumford CJ, Wood NW, Kellar-Wood H, Thorpe JW, Miller DH, Compston DAS 1994 The British Isles survey of multiple sclerosis in twins. Neurology 44:11-15

40. Ebers GC, Sadovnick AD, Risch NJ 1995 A genetic basis for familial aggregation in multiple sclerosis. Nature 377:150-156

41. Sadovnick AD, Ebers GC, Dyment DA, Risch NJ 1996 Evidence for genetic basis of multiple sclerosis. Lancet 347:1728-1730

42. Ebers GC, Kukay K, Bulman DE, Sadovnick AD, Rice G, Anderson C, Armstrong H, Cousin K, Bell RB, Hader W, Paty DW, Hashimoto S, Oger J, Duquette P, Warren S, Gray T, O'Connor P, Nath A, Auty A, Metz L, Francis G, Paulseth JE, Murray TJ, Pryse-Phillips W, Risch N 1996 A full genome search in multiple sclerosis. Nat Genet $13: 472-476$

43. Chataway J, Feakes R, Coraddu F, Gray J, Deans J, Fraser M, Robertson N, Broadley S, Jones H, Clyaton D, Goodfellow P, Sawcer S, Compston A 1998 The genetics of multiple sclerosis: principles, background and updated results of the United Kingdom systematic genome screen. Brain 121:1869-1887

44. Coraddu F, Sawcer S, D`Alfonso S, Lai M, Hensiek A, Solla E, Broadley S, Mancosu C, Pugliatti M, Marrosu MG, Compston A 2001 A genome screen for multiple sclerosis in Sardinian multiplex families. Eur J Hum Genet 9:621-626

45. Dyment DA, Willer CJ, Scott B, Armstrong H, Ligers A, Hillert J, Paty DW, Hashimoto S, Devonshire V, Hooge J, Kastrukoff L, Oger J, Metz L, Warren S, Hader W, Power C, Auty A, Nath A, Nelson R, Freedman M, Brunet D, Paulseth JE, Rice G, O'Connor P, Duquette P, Lapierre Y, Francis G, Bouchard JP, Murray TJ, Bhan V, Maxner C, Pryse-Philips W, Stefanelli M, Sadovnick AD, Risch N, Ebers GC 2001 Genetic susceptibility to MS: a second stage analysis in Canadian MS families. Neurogenetics 3:145-151

46. The Transatlantic Multiple Sclerosis Genetics Cooperative 2001 A meta-analysis of genomic screens in multiple sclerosis. Mult Scler 7:3-11

47. Lassmann H, Bruck W, Lucchinetti C 2001 Heterogeneity of multiple sclerosis pathogenesis: implications for diagnosis and therapy. Trends Mol Med 7:115-121

48. Kerlero de Rosbo N, Brok HP, Bauer J, Kaye JF, 't Hart BA, Ben-Nun A 2000 Rhesus monkeys are highly susceptible to experimental autoimmune encephalomyelitis induced by myelin oligodendrocyte glycoprotein: characterisation of immunodominant T- and B-cell epitopes. J Neuroimmunol 110:83-96

49. Stefferl A, Brehm U, Linington C 2000 The myelin oligodendrocyte glycoprotein (MOG): a model for antibody-mediated demyelination in experimental autoimmune encephalomyelitis and multiple sclerosis. J Neural Transm Suppl 58:123-133

50. Iglesias A, Bauer J, Litzenburger T, Schubart A, Linington C 2001 T- and B-cell responses to myelin oligodendrocyte glycoprotein in experimental autoimmune encephalomyelitis and multiple sclerosis. Glia 36:220-234

51. Duchan AR, Winter G 1988 The binding site for C1q on IgG. Nature 332:738-740

52. Johns TG, Bernard CCA 1997 Binding of complement component C1q to myelin oligodendrocyte glycoprotein: a novel mechanism for regulating CNS inflammation. Mol Immunol 34:33-38

53. Wucherpfenning KW, Strominger JL 1995 Molecular mimicry in T cell-mediated autoimmunity: viral peptides activate human $\mathrm{T}$ cell clones specific for myelin basic protein. Cell 80:695-705

54. Mokhtarian F, Zhang Z, Shi Y, Gonzales E, Sobel R 1999 Molecular mimicry between a viral peptide and a myelin oligodendrocyte glycoprotein peptide induces autoimmune demyelinating disease in mice. J Neuroimmunol 95:43-54

55. Hudson LD, Ko N, Kim JG 1996 Control of myelin gene expression. In: Richardson WD, Jessen KR (eds) Glial cell development. Basic principle of clinical relevance. Bios Scientific Publishers, Oxford, pp 101-121

56. Rodriguez D, Della Gaspera B, Zalc B, Hauw JJ, Fontaine B, Edan G, Clanet M, Dautigny A, Pham-Dinh D 1997 Identification of a Val 145 Ile substitution in the human myelin oligodendrocyte glycoprotein: lack of association with multiple sclerosis. Mult Scler 3:377-381

57. Barcellos LF, Thomson G, Carrington M, Schafer J, Begovich AB, Lin P, Xu XH, Min BQ, Marti D, Klitz W 1997 Chromosome 19 single-locus and multilocus haplotype associations with multiple sclerosis. JAMA 278:1256-1261

58. Roth MP, Dolbois L, Borot N, Pontarotti P, Clanet M, Coppin H 1995 Myelin oligodendrocyte glycoprotein (MOG) gene polymorphisms and multiple sclerosis: no evidence of disease association with MOG. J Neuroimmunol 61:117-122

59. Roth MP, Dolbois L, Borot N, Amadou C, Clanet M, Pontarotti P, Coppin H 1995 Three highly polymorphic microsatellites at the human myelin oligodendrocyte glycoprotein locus, $100 \mathrm{~kb}$ telomeric to HLA-F: characterization and relation to HLA haplotypes. Hum Immunol 43:276-282

60. Seboun E, Oksenberg JR, Rombos A, Usuku K, Goodkin DE, Lincoln RR, Wong M, Pham-Dinh D, Boesplug-Tanguy O, Carsique R, Fitoussi R, Gartioux C, Reyes C, Ribierre F, Faure S, Fizames C, Gyapay G, Weissenbach J, Dautigny A, Rimmler JB, Garcia ME, Pericak-Vance MA, Haines JL, Hauser SL 1999 Linkage analysis of candidate myelin genes in familial multiple sclerosis. Neurogenetics 2:155-162

61. Risch N, Merikangas K 1996 The future of genetic studies of complex human diseases. Science 273:1516-1517

62. Terwilliger JD, Goring HH 2000 Gene mapping in the 20th and 21st centuries: statistical methods, data analysis, and experimental design. Hum Biol 72:63-132

63. Brown J, Hinks L, Thompson RJ 1998 Lack of association of a TaqI polymorphism of the human myelin oligodendrocyte gene with multiple sclerosis in a population of patients from the Southampton area. J Neurol Neurosurg Psychiatry 64:135-136 